\title{
The providing durability of the movable square- sided spline joints by electromechanical treatment of the working surfaces
}

\author{
Alexander Morozov ${ }^{1, *}$, Gennady Fedotov ${ }^{1}$, Lilia Fedorova ${ }^{2}$, Damir Musharapov ${ }^{1}$ and Lilia \\ Khabieva $^{1}$ \\ ${ }^{1}$ Federal State Budgetary Educational Institution of Higher Education Ulyanovsk State Agrarian \\ University, Ulyanovsk, Russian Federation \\ ${ }^{2}$ Federal State Budgetary Educational Institution of Higher Education Bauman Moscow State \\ Technical University, Moscow, Russian Federation
}

\begin{abstract}
The article deals with the operating conditions and causes of loss of performance of movable involute splines joints. In order to ensure the durability of the movable involute splines joints, an effective method of hardening the working surfaces of the splined hub by electromechanical treatment is proposed. The influence of the current on the change of microstructure and microhardness in the electromechanical processing of the working surfaces of the spline bushing was determined. The obtained results of the comparative wear testing of samples involute splines joints depending on the time of testing. It is established that the use of electromechanical processing of the working surfaces of involute splines joints allows reducing the time of their running-in and increasing the wear resistance of the movable joints up to 2 ... 2.5 times.
\end{abstract}

\section{Introduction}

In domestic and foreign automotive and agricultural machinery to transfer power from the power unit to the engines, working bodies and other units and units of the machine are widely used splined connections. In the domestic engineering industry the most widespread involute splines is made (80...90\%). [1]

The performance of the splined connection is affected by the violation of the alignment of the joint, technical malfunctions and breakdowns of the driven working bodies, nodes, various road and soil-climatic conditions, depth of tillage, clogging, soil adhesion and a number of other factors. Therefore, the durability of splined connections of technics operating in conditions of high dust and humidity is quite low. The need to improve the performance properties of splined connections increases, as the power transmitted by the power units is steadily enhancing.

The kind of damage to splined joints depends on the operating conditions, their design features, the manufacturing technology of the shaft and splined hub, as well as a number of other factors.

\footnotetext{
*Corresponding author: alvi.mor@mail.ru
} 
It is established that the main cause of loss of operability of mobile square-sided spline connections is the wear out of contacting lateral surfaces of splines of a shaft and a splined hub. In this regard, the relevant direction of increasing the wear resistance and durability of splined joints is the use of effective strengthening technologies.

For hardening work surfaces splines components is widespread case-hardening by high frequency currents. Due to the technological features, this method is mainly used to harden the working surfaces of spline shafts, but it is not applicable for hardening splined hub, especially small (less than $40 \mathrm{~mm}$ ) diameter. At the moment, there are no effective technologies of surface hardening of the working surfaces of splined hubs of small diameter. In this case, the splined hubs are allowed to operate with low performance properties of the working surfaces, which significantly reduce their service life. The formation of internal spline profiles is more labor-intensive and costly process than splines on shafts and increasing their durability is an important technical and economic task.

As a result of previous studies [2, 3, 4, 5, 6, 7], a high efficiency of electromechanical processing (EMP) is established as applied to the working surfaces of parts of movable joints.

This work aims at to study the influence of EMP of the working surfaces of the movable square-sided spline joints for their wear resistance.

\section{Methodology of Experiment}

The proposed EMP scheme of the spline bushing working surfaces is shown in Fig.1.

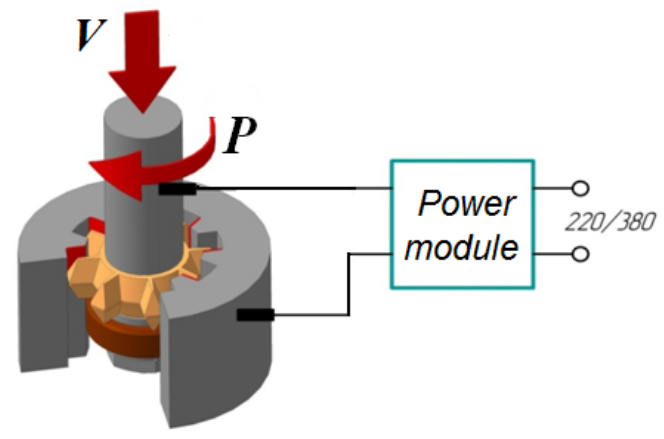

Fig. 1. The scheme of the process of electromechanical hardening of the working surfaces of the splined hub: $V$ - the speed of the tool; $P$ - the force of pressing the tool to the side surface of the slot.

EMP of working surfaces of splined hubs is made by the spline tool (the number of splines of the tool corresponded to the number of splines of the hub) $[6,8,9,10]$ of chromium copper BCr1. On the tool installed in the upper part of the splined hub and prepressed to the side the surfaces of the slots, and the splined hub is supplied with a current of high force and low voltage, simultaneously moving the tool to the bottom of the splined hub. After moving the tool to the bottom of the splined hub current is switched off, the tool is rotated in the opposite direction, it is pressed against the opposite side surfaces of the splined hub slots, then re-turns on the electric current of the same force, and the tool is vertically moved to the top of the splined hub.

To assess the quality of the working surface of the splined hub after EMP and predict its durability, metallographic studies of the resulting structure and bench wear tests were carried out.

Bench tests are an important step in the comprehensive assessment of the effectiveness of strengthening technologies for parts and joints exposed to various types of wear. Tested 
for wear resistance splines joints were conducted on a specially arranged stand on the base of the horizontal shaper machine. (Fig. 2).

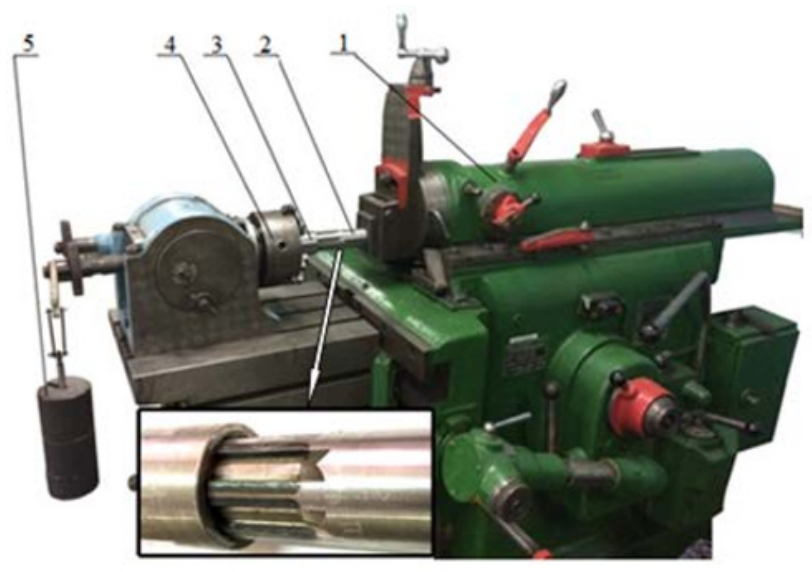

a

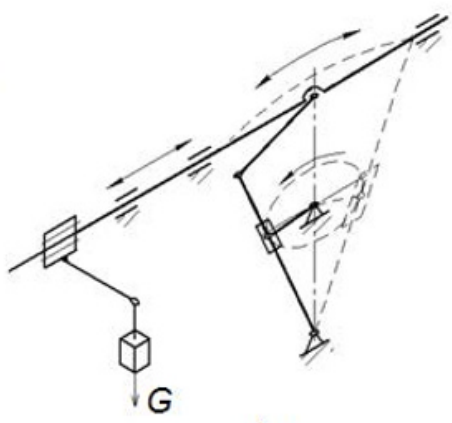

$b$

Fig. 2. Stand for research of wear resistance of movable splines: a - General view of the stand: 1 horizontal shaper machine 7Б35; 2 - experimental splined shaft; 3 - experimental splined hub; 4 universal dividing head UDH-160; 5 - static loader; b - kinematic scheme of the stand: G - the weight of the load, $\mathrm{N}$.

The splined shaft was fixed in the caliper of the horizontal shaper machine, the main movement of which is straight reciprocating motion. The splined hub was installed in the cartridge of the universal dividing head. The load on the working surfaces of the splined joint was set by means of a calibrated static loader. The duration of studies was 24 hours for each spline joint, the moment of force produced by static loader was $10 \mathrm{~N} \cdot \mathrm{m}$. In the friction zone of working surfaces of the analyzing samples splines were added $5 \%$ by weight from the pinion grease (Lithol - 24) of quartz dust.

After the tests, the samples were washed in kerosene and dried in a cabinet dryer for 30 minutes at $353^{\circ} \mathrm{K}$. Measurements of the size of the working surfaces of the spline shafts were made using a micrometer type MK-25. Measurement was made for each slot in three equidistant planes from the end of the spline shaft.

Measurements of the size of the working surfaces of the splined hubs before and after the tests were performed using a digital caliper with an electronic display scale and a division value of $0.01 \mathrm{~mm}$. Measurement of roughness of working surfaces of the parts splined joints before and after bench tests was performed on the profilometer model 130.

\section{Research Results and Discussion}

After EMP on the working surfaces of the slots formed areas of dark color (Fig. 3), which typically for tempered areas. Basically, they had a segment form, indicating the temperature characteristic of EMP exposure. 

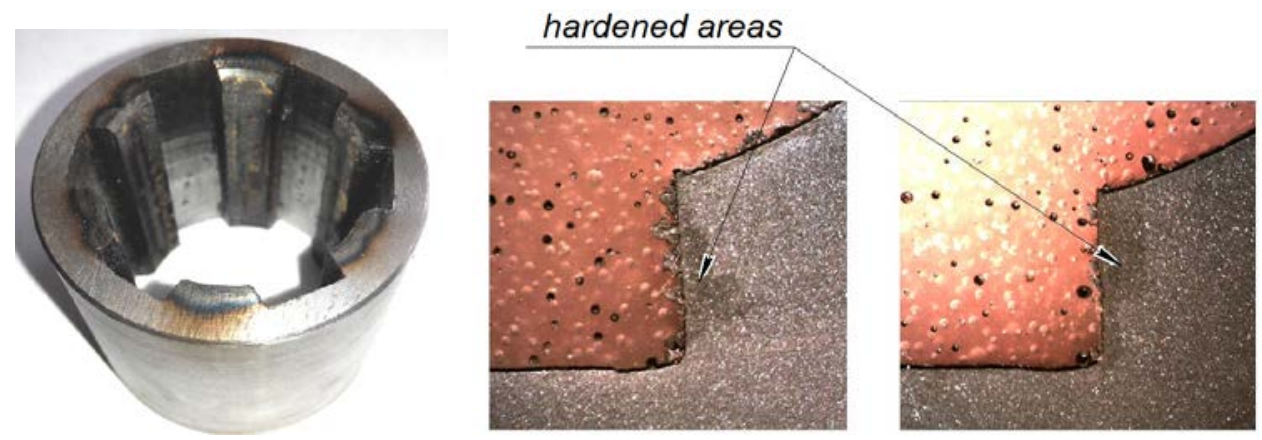

Fig. 3. Hardened side surfaces of the spline sleeve after EMP. Steel 40Cr.

High wear resistance of the hardened areas is given by structureless martensite, characterized by a large dispersion of the structure, significant inhomogeneity and significant distortions of the crystal lattice.

Figures 4 and 5 show the microstructures of the splined surface layer which are made by EMP-hardened.
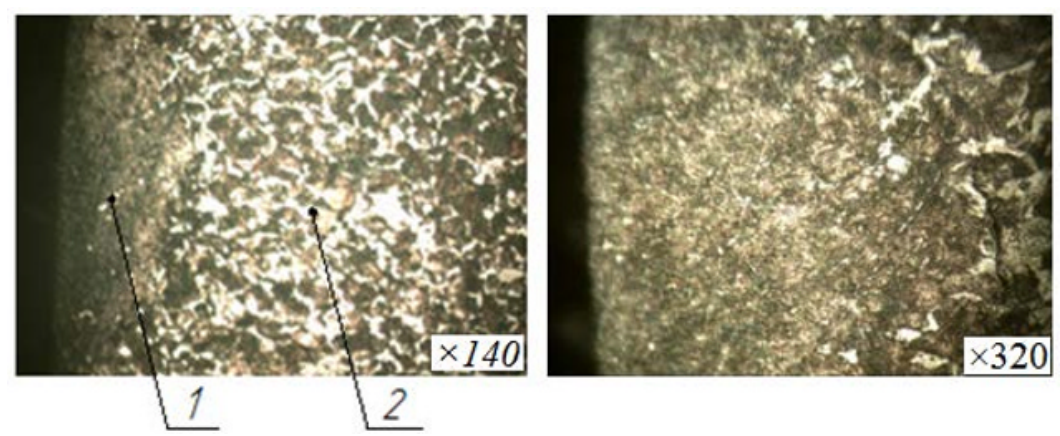

Fig. 4. The microstructure of the working surface of the splined hub after the EMP. Steel 40Cr: $1-$ martensitic structure; 2 - ferrite-pearlite structure.

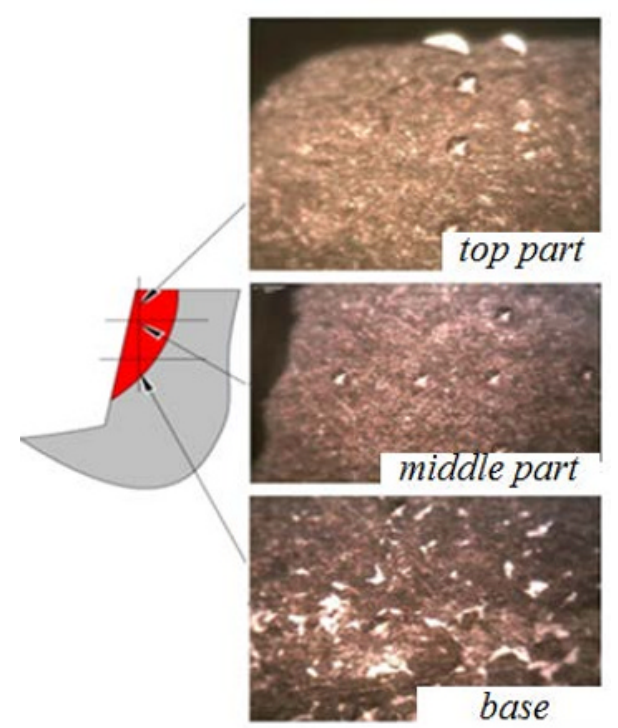

Fig. 5. The microstructure of sections of the spline after the EMP influence. Steel $40 \mathrm{Cr} ; \times 320$. 
During high-speed heating hypoeutectoid steel in the conditions of the EMP occurs non-diffuser transformation of structurally free ferrite in carbon-free $\gamma$-iron, that is no interaction between him and a carburized (case-hardened) austenite. With an increase in the rate of heating, the dissolution of excess ferrite in austenite is gradually "suppressed", as a result of which an increasing part of the ferrite is heated to higher temperatures, at which thermodynamic prerequisites are created for its diffusion-free transformation into $\gamma$-iron, typical for pure iron, followed by the formation of low-carbon martensite in such areas [2].

Figure 6 shows the distribution of hardness over the depth of the working surfaces of the splines of the studied samples treated with EMP. Microhardness was measured in the center of the hardened portion.

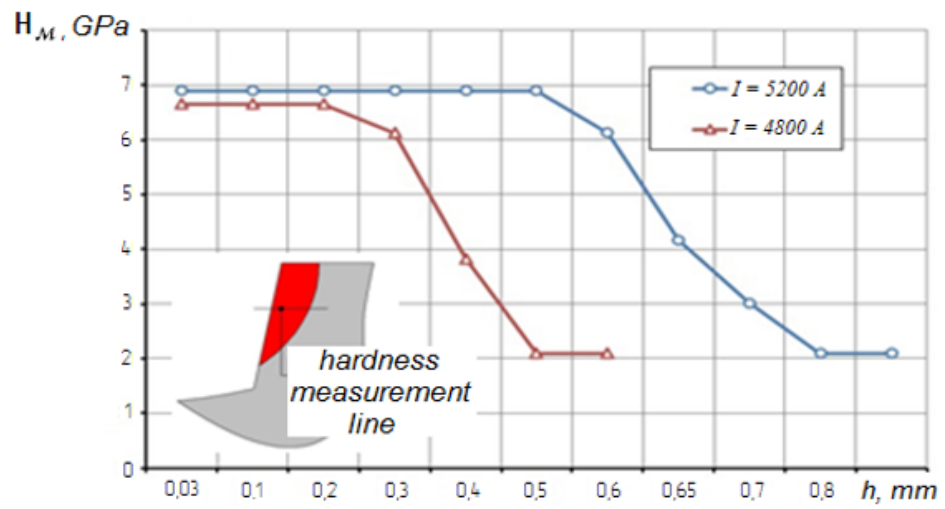

Fig. 6. Distribution of microhardness over the thickness of the hub's spline after EMP. Steel 40Cr, $V=66 \mathrm{~m} / \mathrm{min}$.

The hardness of the EMP-treated working surfaces of the hub's splines at a current of I $=5200 \mathrm{~A}$ increased to $6.87 \mathrm{GPa}$ (Fig. 6), which is almost 3 times the original hardness. Depth of the hardened layer in this EMP mode is $0.6 \mathrm{~mm}$. At a current strength of $\mathrm{I}=4800$ A and a slight decrease in hardness, the depth of the hardened layer was $0.3 \mathrm{~mm}$.

Comparative bench studies were subjected to splined connections, the characteristics of which are given in Table. 1.

Table 1. Characteristics of splined joints $(6 \times 28 \times 34)$ made of $40 \mathrm{Cr}$ steel.

\begin{tabular}{|c|c|c|c|}
\hline $\begin{array}{l}\text { № } \\
\Pi / \Pi\end{array}$ & Detail & Hardness, HV, GPa & $\begin{array}{l}\text { Surface roughness } \\
\text { Ra, mkm }\end{array}$ \\
\hline \multicolumn{4}{|c|}{ Splined connection No. 1} \\
\hline 1 & Non-hardened splined shaft & 2.57 & $2.0 \ldots 2.4$ \\
\hline 2 & Non-hardened spline sleeve & 2.64 & $2.0 \ldots 2.4$ \\
\hline \multicolumn{4}{|c|}{ Splined connection No. 2} \\
\hline 3 & $\begin{array}{l}\text { Splined to the shaft after the splines EMP: } \\
I=700 \mathrm{~A}, V=40 \mathrm{~mm} / \mathrm{min} \text {. }\end{array}$ & 7.23 & $1.2 \ldots 1.6$ \\
\hline 4 & Non-hardened splined hub & 2.64 & $2.0 \ldots 2.4$ \\
\hline \multicolumn{4}{|c|}{ Splined connection No. 3} \\
\hline 5 & $\begin{array}{l}\text { Splined to the shaft after the splines EMP: } \\
\mathrm{I}=700 \mathrm{~A}, \mathrm{~V}=40 \mathrm{~mm} / \mathrm{min} \text {. }\end{array}$ & 7.25 & $1.2 \ldots 1.6$ \\
\hline 6 & $\begin{array}{l}\text { Splined hub after EMP: } \mathrm{I}=700 \mathrm{~A}, \mathrm{~V}=66 \\
\mathrm{~mm} / \mathrm{min} \text {. }\end{array}$ & 6.9 & $1.1 \ldots 1.6$ \\
\hline
\end{tabular}

Figure 7 shows the dependence of wear for the working surfaces of the investigated friction pairs on the duration of the study at a moment of force $M=10 \mathrm{~N} \cdot \mathrm{m}$. 


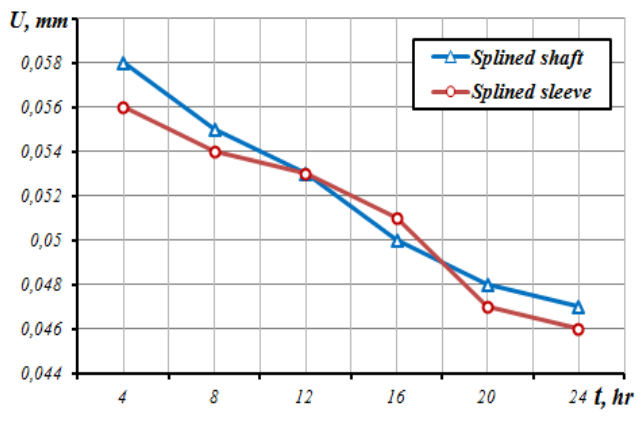

a

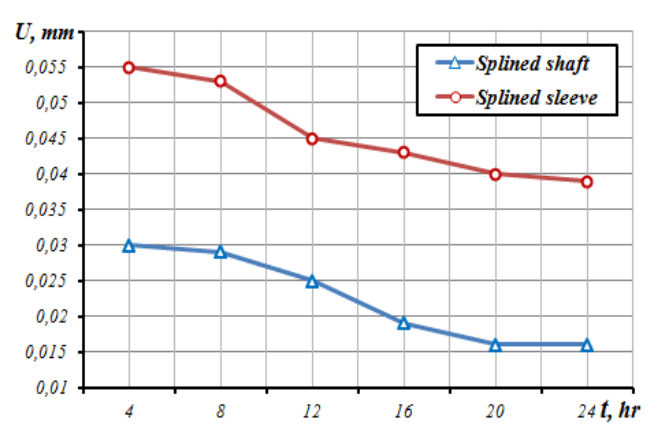

$\mathrm{b}$

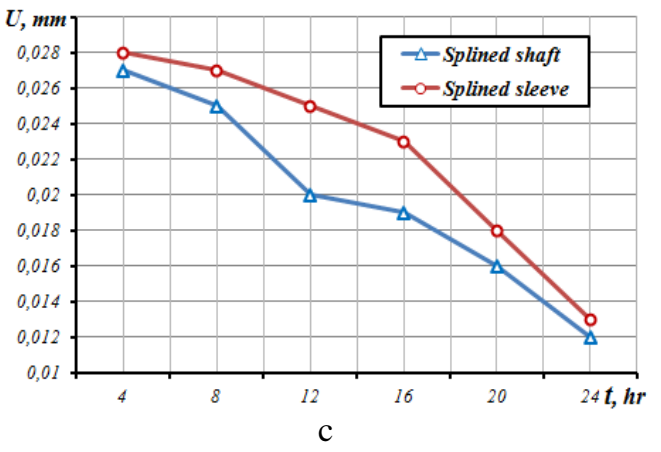

Fig. 7. Dependence of the wearing for working surfaces of parts movable splines on the duration of the study: a - spline connection No.1; b - spline connection No.2; c - spline connection No.3.

As a result of bench studies of splined connection No.1, it was found that the average wear of the working surfaces of the splined shaft was $0.05 \mathrm{~mm}$, and that of the splined hub $0.051 \mathrm{~mm}$ (Fig. 7, a). During the same period of studies of splined connection No. 2, the average wear of the working surfaces of the splined shaft was $0.023 \mathrm{~mm}$, and the splined hub was $0.046 \mathrm{~mm}$ (Fig. 7, b), which is 1.46 times less than the total wear of splined joint No.1. Research of splined connection No. 3 showed that the average wear of the working surfaces of the splined shaft was $0.019 \mathrm{~mm}$, and the splined hub was $0.022 \mathrm{~mm}$ (Fig. 7, c), which is 1.68 times less than the total wear of the friction pair No. 2 and 2.46 times less than the total wear of the friction pair No. 1.

After research the roughness of the working surfaces standard shafts and splined hub decreased from RA $=2.46 \mathrm{mkm}$ up to $\mathrm{RA}=1.70 \mathrm{mkm}$, and the roughness of the working surfaces of spline shaft and hub after EMP has decreased slightly, from RA $=1.65 \mathrm{mkm}$ to $\mathrm{RA}=1.62 \mathrm{mkmIn}$ view of the foregoing, it follows that the use of EMP working surfaces of slots of hubs and shafts can reduce the running-in time and wear of mating surfaces.

\section{Conclusion}

The overall force and high-temperature impact on steel at EMP gives the surface unique properties: structureless martensite has both high hardness and resilience, which can significantly increase the durability of splined surface matching operating under conditions of abrasive wear and high contact loads during reversal.

It is found that increasing the current from I $=4800$ A to I $=5200$ A at EMP working surfaces of splined hub leads to a significant (2.5 times) increase in the depth of the hardened areas with an increase in their hardness by $7 \%$.

In accordance with the obtained results it follows that the use of EMR working surfaces of splined joints, can increase their wear resistance from 1.7 to 2.5 times. 


\section{References}

1. G.I. Skundin, V.N. Nikitin, Splined connections (Shlitsevyye soyedineniya), Mashinostroenie, (1981)

2. V.P. Bagmutov, S.N. Parshev, N.G. Dudkina, I.N. Zakharov, Electromechanical processing: technological and physical foundations, properties, implementation (Elektromekhanicheskaya obrabotka: tekhnologicheskiye i fizicheskiye osnovy, svoystva, realizatsiya), Science, (2003)

3. L.V. Fedorova A.V. Morozov, V.A. Freeling, Increasing the efficiency of electromechanical hardening of holes of smooth cylindrical movable joints experiencing a one-sided radial load (Povysheniye effektivnosti elektromekhanicheskogo uprochneniya otverstiy gladkikh tsilindricheskikh podvizhnykh soyedineniy, ispytyvayushchikh odnostoronnyuyu radial'nuyu nagruzku) Magazine " Repair, restoration, modernization". 8, 49-52 (2012)

4. A.V. Morozov, G.D. Fedotov, Development of the classification of electromechanical processing of holes by a moving high-temperature strip source (Razrabotka klassifikatsii protsessov elektromekhanicheskoy obrabotki otverstiy dvizhushchimsya vysokotemperaturnym polosovym istochnikom) Magazine "Strengthening technologies and coatings". 3, 44-50 (2015)

5. A.V. Morozov, V.A. Freeling, N.I. Shamukov, Improving the wear resistance of holes of parts subject to bilateral wear using selective electromechanical hardening (Povysheniye iznosostoykosti otverstiy detaley, podverzhennykh dvustoronnemu iznosu, $\mathrm{s}$ pomoshch'yu selektivnogo elektromekhanicheskogo uprochneniya) Bulletin of the Ulyanovsk State Agricultural Academy. 4, 113-119 (2013)

6. A.V. Morozov, G.D. Fedotov S.N. Petryakov, A.Yu. Gorshkov, D.R. Musharapov Features of the choice of tool for electromechanical machining of holes of machine parts a strip high-temperature source (Osobennosti vybora instrumenta dlya elektromekhanicheskoy obrabotki otverstiy detaley mashin polosovym vysokotemperaturnym istochnikom) Tidings of Tula State University. Technical science. 7(2), 258 - 268 (2016)

7. L.V. Fedorova, S.K. Fedorov, A.A. Serzhant, V.V. Golovin, S.V. Systerov, Electromechanical Surface Hardening of Tubing Steels (Elektromekhanicheskoye uprochneniye trubnykh staley) Magazine "Metal Science and Heat Treatment". 3, 41-43 (2017)

8. A.V. Morozov, N.N. Gorev, D.R. Musharapov, Tool for electromechanical hardening of working surfaces of splined bushings (Instrument dlya elektromekhanicheskoy zakalki rabochikh poverkhnostey shlitsevykh vtulok) Patent RF,no. 2572677 (2016)

9. A.V. Morozov, D.R. Musharapov, E.A. Tokmakov, Tool for electromechanical hardening of working surfaces of splined bushings (Instrument dlya elektromekhanicheskoy zakalki rabochikh poverkhnostey shlitsevykh vtulok) Patent RF,no. 2620533 (2017)

10. A.V. Morozov, A.E. Abramov, D.R. Musharapov, Tool for electromechanical hardening of working surfaces of splined bushings (Instrument dlya elektromekhanicheskoy zakalki rabochikh poverkhnostey shlitsevykh vtulok) Patent RF,no. 167360 (2017) 